\title{
Educação, hegemonia e terceiro setor na região metropolitana de Campinas
}

Marcos Roberto Lima

Mestrando em Educação pelo HISTEDBR/Unicamp

\section{Resumo}

Esta pesquisa tem por objetivo realizar uma análise de projetos educacionais desenvolvidos por ONGs da RMC, tendo por cenário o período de aplicação das novas diretrizes neoliberais como tentativa de saída do capital para sua crise estrutural, sobressaindo-se a implementação da reestruturação produtiva, privatizações e a política do Estado mínimo, culminando em um processo de (des)sociabilização, cuja crítica das formas de representação, destacando-se a ação estratégica do chamado terceiro setor e sua pedagogia do consenso, aplicadas por este Estado educador, se faz imprescindível.

Palavras-chave: Educação; Terceiro Setor; Hegemonia.

\begin{abstract}
This project has for objective to carry out analysis of educational projects developed by ONGs of the RMC, having for scene the period to the application of the new neoliberal directives how attempt way out capital for its structural crisis, stand out the implementation of the productive restructuration, privatizations and politic of the minimum State, culminating in a process of (des)sociabilization, whose critic of representation forms, stand out it strategical action of the call third sector and it pedagogy of the consensus, applied for this educator State, it's make necessary.
\end{abstract}

Keywords: Education; Third Sector; Hegemony. 
$\mathrm{E}$

m princípio, poderíamos destacar uma justificativa de ordem pessoal para a elaboração deste projeto, tendo em vista a experiência adquirida em 12 anos como professor da Rede Pública Estadual de Ensino. O contato cotidiano com o discurso oficial da autonomia e participação e a nova roupagem da "cidadania ativa", característica da terceira via, nos levaram a questionar seus limites e efeitos desvinculantes das responsabilidades governamentais. Longe de ser uma observação isolada, tal questionamento foi elaborado à luz da socialização de experiências nos Congressos Educacionais e Reuniões de Representantes de Escola (RR) organizados pela APEOESP (Associação dos Professores do Ensino Oficial do Estado de São Paulo).

Estas considerações de ordem pessoal se tornam pertinentes devido à relevância do projeto. Como tentativa de saída do capital para sua crise estrutural, são implementadas a reestruturação produtiva, as privatizações e a política do Estado mínimo, criando todo um processo de (des)sociabilização cuja crítica se faz imprescindível para a desfetichização das formas de representação, destacando-se o "terceiro setor" e o culto ao comunitarismo, impostos através da "pedagogia do consenso" aplicada por este Estado educador (NEVES, 2005).

Como reconhece Ricardo Antunes, uma análise que se limite especificamente aos aspectos econômicos da nova roupagem do capital não dará conta da complexidade da abordagem necessária para a compreensão do papel cumprido pelo terceiro setor na implementação das políticas neoliberais. As associações solidárias se convertem em uma nova forma de mistificação, uma vez que, como saída para o desemprego estrutural, apresentam-se de forma efetiva, porém limitadíssima (ANTUNES, 2005, p. 114).

A educação passa a ter um importante papel, uma vez que as transformações na base produtiva, através da reestruturação flexível e automatização da produção têm se caracterizado pela grande liberação da força de trabalho humana impondo novas relações sociais (SAVIANI, 2005, p. 21). Prevalece, segundo Gaudêncio Frigotto, a vulgata das habilidades e 
competências e a promessa da empregabilidade, o que fortemente se apóia nos fundamentos pós-modernos que realçam as diferenças individuais e a alteridade. O capitalismo, em sua fase tardia, procura então, instrumentalizando os projetos educacionais, convencer os excluídos de sua culpa pela exclusão (FRIGOTTO, 2005, p. 71-72).

É a partir da compreensão dessas transformações em curso que procuramos realizar a crítica ao terceiro setor e seu desenvolvimento na RMC, entendendo toda a trama neoliberal que o perpassa e legitima através da imposição do consenso. A ampliação do campo de atuação das ONGs e seus projetos educacionais se dá no momento em que, equivocadamente, se confunde o Estado mínimo com o definhamento do Estado Moderno. Ao que parece seu papel continua imprescindível para o capital como estrutura corretiva e totalizadora (MÉSZÁROS, 2002, p. 106-107). A negativa do compromisso ideológico da sociedade civil e sua desvinculação do Estado e do mercado, própria do neoliberalismo de terceira via, que a sustenta teórico-filosófica e ético-politicamente, cria a concepção de uma nova identidade chamada terceiro setor (MONTAÑO, 2007, p. 54).

Para desmistificar esse constructo ideológico liberal que separa público e privado (LOMBARDI, 2005, p. 79), um dos elementos que norteiam o debate sobre o terceiro setor, nos baseamos no método da economia política de Marx, tal qual o exposto no Prefácio à Critica da Economia Política:

[...] na produção social da própria vida, os homens contraem relações determinadas, necessárias e independentes de sua vontade, relações de produção estas que correspondem a uma etapa determinada de desenvolvimento das suas forças produtivas materiais (MARX e ENGELS, 1996, p. 52).

Portanto, a compreensão do objeto em questão não será buscada em sua aparência fenomênica, mas em sua relação, enquanto sujeito, com a estrutura e suas determinações, em tensão e mútua imbricação dialética (FRIGOTTO, 2005, p.70), entendendo o Estado a partir da concepção gramsciana, que não se limita à observação de sua atuação coercitiva, 
buscando analisar os diferentes meios através dos quais um novo tipo de civilização se faz hegemônico.

\section{Referências bibliográficas}

ANTUNES, R. Os sentidos do trabalho. São Paulo, Boitempo editorial, 2005.

FRIGOTTOO, G. Estruturas e Sujeitos e os Fundamentos da Relação Trabalho e Educação. In: Saviani e Sanfelice (orgs). Capitalismo, trabalho e educação. Campinas-SP, Autores Associados, HISTEDBR, 2005.

LOMBARDI, J. C. Público e privado como categorias de análise da educação. In: LOMBARDI, JACOMELI e SILVA (orgs.). O público e o privado na história da educação. Campinas-SP, Autores Associados, HISTEDBR, Unisal, 2005.

MARX, K.; ENGELS, F. Prefácio à Critica da Economia política. Os pensadores, Nova cultural, 1996.

MÉSZÁROS, I. Para além do capital. Campinas SP, Unicamp, Boitempo editorial, 2002.

MONTAÑO, C. Terceiro Setor e questão social: crítica ao padrão emergente de intervenção de intervenção social. $4^{\circ}$ edição, São Paulo, Cortez, 2007.

NEVES, L. M. W. (org.). A nova pedagogia da hegemonia - estratégias do capital para educar o consenso. São Paulo, Xamã, 2005.

SAVIANI, D. Transformações do Capitalismo, do Mundo do Trabalho e da Educação. In: SAVIANI e SANFELICE (orgs.). Capitalismo, trabalho e educação. Campinas-SP, Autores Associados, HISTEDBR, 2005. 